\title{
A CLINICAL ECONOMY OF SPECULATION: Financial Trading and Gambling Disorder in Spain
}

\author{
JORGE NÚÑNEZ \\ University of California, Davis \\ (D) http://orcid.org/0000-0001-6266-7052
}

"Did you know that a brokerage firm can lend you up to fifty times your real trading capacity?" Yes, I replied, knowing that the question was a rhetorical one. "Well, that's what got me here," said Silvia during our interview at the psychiatric clinic of the Catalonia University Hospital (CUH). ${ }^{1}$ Silvia was a fiftysomething financial trader who had been diagnosed with gambling disorder, an entrepreneurial woman who, after quitting her job in a medium-size bank, set up shop as a freelance trader in her small hometown near Barcelona. ${ }^{2}$ When I interviewed Silvia in early 2013, she was under clinical treatment for gambling disorder and had various pending lawsuits for defrauding former clients and friends of more than half a million euros.

This article concerns itself with Silvia and the clinical economy of her transformation from financial trader to problem gambler. In examining the medicalization of trading as gambling disorder during the Spanish financial crisis of 2007 to 2015, I show that the mobilization of clinical resources was not simply a matter of regulating financial markets. In the process, new lines were being drawn around the concept of proper speculation. This article develops the concept of a clinical economy of speculation, which refers to "the exchange of symptoms for diagnosis and treatments" (Davis 2010, 155) through which the category of the problem gambler is repurposed to include financial traders. This focus brings into view the redefinition of credit and debt within the domain of trading to make an 
intervention into the anthropology of finance (Knorr Cetina 2003; Zaloom 2006; Lépinay 2011; Loussouarn 2013; Miyazaki 2013; Allon 2015; Sabaté 2016). My main argument is that the pathologization of trading in Spain has taken place against the backdrop of a multiscalar process of credit and debt surveillance implemented in response to excessive financial leverage. This regulatory process begins at the European Union (EU) level, passes through the Spanish state, and reaches everyday people through gambling diagnosis and treatment. In this context, mental disorder is what separates true traders from problem gamblers, and financial failure becomes the tipping point between speculation and gambling. Put differently, I argue that gambling disorder is part of an expansive postcrisis credit and debt regime that puts the blame on the individual while protecting the financial system at all costs.

In the Spanish context, the pathologization of trading coincided with the socalled Great Recession, a never-ending crisis in banking that turned a foreclosure crisis into a sovereign debt crisis through an aggressive taxpayer-backed bailout policy. As Jaime Palomera $(2015,42)$ puts it, "what had begun as a private debt problem became a public debt crisis." The hinge institution between these two crises was the Fund for Orderly Bank Restructuring (the Spanish acronym is FROB). Created by the Spanish government in 2009, it transferred more than fifty billion euros to cash-starved banks swamped with mortgage defaults. While foreclosures and evictions soared, leaving millions highly indebted (Suarez 2017, 24), FROB officials requested a one-hundred-billion-euro rescue package from the European Union to recapitalize the Spanish banking system. As the crisis in banking intensified and escalated, FROB measures kept burdening the government budget, which slipped from recording a surplus (2.2 percent of GDP) to recording a deficit (11.2 percent of GDP) in four years. Meanwhile, public debt nearly tripled between 2008 and 2014 (Charnock, Purcell, and Rivera-Fumaz 2014, 111). To put it briefly, the FROB's approach to the Great Recession seemed to postulate that the larger the bank, the greater the bailout should be.

The bailout policies of the FROB take on a different significance when we compare them to the medical model of trading. In that model, clinicians teach insolvent traders to see their actions as antisocial and irrational, even though their debt-fueled speculative practices emulate those of banks and other financial institutions rescued by the central government. For instance, the FROB spent 4.5 billion euros to partially nationalize Spain's fourth-largest bank after a fraudulent stock market listing that involved its chairman Rodrigo Rato, a former high-level politician and International Monetary Fund (IMF) director. However, until 2015, 
no indictments were issued. ${ }^{3}$ This starkly differential distribution of punishment calls for an exploration of widening inequalities across the field of investment in Spain, between institutions and individuals as well as between women and men.

What can Silvia's diagnosis and treatment as a disordered gambler tell us about the regulatory mechanisms of credit and debt implemented during the Spanish financial crisis? And what can her life history teach us about the maledominated world of trading in Spain? As I argue in this article, the medicalization of trading in Spain can initially be understood in light of nineteenth-century politico-legal debates about stock-market gambling. This approach offers a particularly advantageous position from which to interrogate whether and why gambling disorder came to be another way of blaming citizens for systemic failures in banking and finance. Is the medicalization of trading a way of depoliticizing financial speculation in a country ridden by bank scandals? Or is the pathologized trader an exemplary figure of postcrisis politics of credit and debt? By looking at the process by which Silvia became a freelance trader and her later clinical encounter with her therapist Nuria, my ethnography analyzes the relationship between financial leverage, austerity measures, and gambling disorder in Spain.

The clinical economy of speculation is not a gender-neutral development. It soon became evident to me that female traders were subjected to greater control than men. I focused on Silvia in my research because she stood out in a highly masculine industry. There are few female traders in Barcelona; the majority work in sales and other customer-service jobs. In this regard, Silvia decenters "the straight white men who inhabit our figurative imaginations" (Appel 2014, 55) of financial markets. Her story makes apparent the gendered register of the crisis concept that Janet Roitman (2013) has called into question for being a blind spot that "obscures more than it reveals and produces as much as it represents" (Davis 2015, 1032). For example, Silvia defies the so-called female solution that emerged from the 2008 global financial crisis and regained momentum three years later during the Eurozone debt crisis. As James Brassett and Lena Rethel (2015, 3) point out, "ideas about Angela Merkel as the good wife have been mobilized to support policies of austerity and fiscal rectitude in the EU." If Merkel represents the epitome of the "good wife" who can save the Eurozone, then Silvia embodies the subversive female whose actions unfold against "the belief that women are more risk averse than men" (Maltby and Rutterford 2014, 516).

The second sibling of a wealthy Catalan family of three sisters and two brothers, Silvia was also the only daughter who never married. She grew up in a small industrial town near Barcelona, surrounded by kin and friends. Silvia was 
frustrated with her situation when she spoke into my audio recorder, flinching every so often as she reran for me various episodes of her life in a pastiche-like manner. Silvia felt that her story remained untold. She kept wondering about when exactly her life had gone astray, caught in a spiral of debt and receiving clinical treatment for her gambling disorder while awaiting a possible prison sentence.

\section{A CLINICAL ECONOMY OF SPECULATION}

Nuria was the head of the Pathological Gambling Unit in the Psychiatry Department at CUH and Silvia's chief therapist. Nuria was a widely published academic involved in long-term research on stock-market investment as a form of gambling. ${ }^{4}$ She had grown into a leading expert in the field after the 1990s machine-gambling boom. ${ }^{5}$ Nuria was working on two papers: a study of the increase in online gambling expenditure during the financial crisis - approximately 30 percent in 2011 — and a comparative analysis of problem gamblers and financial traders under clinical treatment. ${ }^{6}$ She saw stock-market gambling as a problem of the future. Although the occurrence of gambling disorder among traders was still relatively low, Nuria expected the phenomenon to continue to grow. "We must take into account that new technologies allow ordinary people full access to financial markets . . . and online trading has become a widespread fad in Spain," said Nuria, adding that she and her colleagues at CUH believed there existed a significant "underdiagnosis" of gambling disorder among traders.

Nuria's studies indicated that pathological gamblers and traders under treatment presented similar clinical profiles. However, socioeconomic characteristics and personality traits differed. As Nuria put it, "in general, traders are better off than gamblers and often have higher levels of education. I'd also say that narcissistic traits are more readily recognizable in traders." Another common characteristic among traders was their acute level of insolvency. "Silvia is my most indebted patient by far; her level of indebtedness is very, very important," said Nuria, before framing Silvia's insurmountable debt as a symptomatic expression of her severe gambling disorder. ${ }^{8}$ Although Nuria and other psychologists and psychiatrists at the hospital with whom I spoke knew little about how credit and debt worked in trading, financial terms gradually became part of their diagnostic repertoire. I observed how their clinical assessments started transitioning from an idea of commercial gambling that clearly distinguished between lending and betting toward an idiom of speculation that conflated the two. This transition entailed the adoption of a context-specific definition of debt as leverage in lieu of the more 
common perception of debt as a debilitating burden (Peebles 2010; Gregory 2012; Allon 2015; James 2015; Stout 2016). The key point here is that the redefinition of debt in terms of leverage presupposes "the disappearance of any real distinction between debt as liability and debt as asset" (Allon 2015, 702).

Leverage refers to debt-fueled financial speculation. In the Spanish stockmarket scene, leveraged trading was synonymous with speculating at a low cost. In Barcelona, for example, there was a famous sales trader who promoted leverage as "free credit to make money." Among the network of freelance traders with whom I interacted regularly, the use of leverage to magnify potential profits (and potential losses) was but a second meaning of trading. Everyone knew that the higher the leverage, the greater the risk. The catch was that leverage came attached to most financial instruments that were available to retailers. As Fiona Allon $(2015$, 694) puts it, "profits are to be made not by investing money, in production or other productive activities, but rather by lending it.”

The way leverage became factored into the diagnosis of gambling disorder among traders is at the center of what I call a clinical economy of speculation. This clinical economy accounts for the process of medicalizing speculative forms of credit and debt. It also recycles deep-rooted antigambling ideologies that have long shaped Spanish financial institutions. Finally, it organizes the aftermath of financial market failure at the individual level. Drawing from medical anthropology (Conrad 1992; Castellani 2000; Davis 2010, 2015; Kitanaka 2012; CrowleyMatoka and True 2012), the anthropology of debt (Peebles 2010, 2012; Gregory 2012; Graeber 2011; Han 2012; Weston 2013; Allon 2015; James 2015), and the anthropology of gambling (Klima 2006; Rizzo 2004; Reith 2007; Schüll 2012; Cassidy, Loussouarn, and Pisac 2013; Cassidy, Pisac, and Loussouarn 2013), I suggest that the clinical economy of speculation extends postcrisis regulatory regimes of credit and debt to the general population. From this perspective, I observe how common speculative practices are seen as sick and unsafe when people instead of banks perform them.

Earlier research on medicalization focused on how social dysfunction and deviance became pathologized (Rosecrance 1985; Conrad 1992; Castellani 2000). This scholarship characterized therapeutic models as a tool of biomedical control that ends up subjecting people to further surveillance (Kitanaka 2012). More recent anthropological analyses of medicalization (Han 2012; Kitanaka 2012; Crowley-Matoka and True 2012) have explored the agency of pathologized individuals and the everydayness of mental illness and addiction. Important critiques of medicalization also exist (Biehl and Moran-Thomas 2009; Davis 2010; Fassin 
2011). Particularly relevant for the purposes of this article is Elizabeth Davis's (2010, 160) remark on the problematic divide between the medical and the political. As she puts it, "mental illness may appear primarily as an index of political crisis, while political crisis takes the social form of mental illness.”

Although I follow Davis $(2010,160)$ in viewing gambling disorder among traders "as a failure of the distinction between medical and political causes and effects," I retain the concept of medicalization because it allows me to analyze how traders become invested, alongside clinicians, in pathologizing financial speculation. In doing so, however, I do not treat "medicalization itself as a symptom of social inequality and social dysfunction in modern states" (Davis 2010, 160). Rather, I make the case for understanding medicalization in dialogue with recent anthropological studies of gambling addiction (Schüll 2012; Garriott and Raikhel 2015). This scholarship sees gambling addiction as a distributed phenomenon across individuals, technologies, and therapeutics. For instance, in studying how financial trading mirrors certain aspects of machine gambling, Caitlin Zaloom (2014, 179-80) shows that the former practice also has "addictive qualities, and requires remedies that address the particular features of technology and money that drive forward destructive habits." What I am interested in depicting here is how the pathologization of trading is simultaneously a mechanism to regulate leverage and an emerging medical field of research and treatment.

Alan Klima (2006) gives us a way to understand how deleveraging mandates imposed by the troika of the European Commission, the European Central Bank, and the IMF on the Spanish financial sector trickled down to freelance traders via gambling therapies. Exploring the lives of habitual gamblers, funeral casino dealers, and small-time moneylenders, Klima discerns the symbiotic relationship between IMF discourse about postcrisis Asian economies and the criminalization of informal credit and debt systems across rural villages in northern Thailand. Klima argues that government officials repurposed IMF moral condemnations of the 1997 Asian financial crisis to denigrate and dismantle credit and debt instruments that reached beyond national control mechanisms. From this vantage point, monetary moralities trickled down from the IMF to local Thai policies (Klima 2006, 34). Likewise, credit and debt regulations on a global scale can trickle down and spread into seemingly unrelated social fields such as mental health. For example, in response to the Eurozone crisis, the European Union created what was called postprogram surveillance to ensure that lending demands were being met by borrowing countries like Spain. ${ }^{9}$ We should not downplay the term surveillance here, as it qualifies the implementation of EU austerity programs across the entire 
region, underscoring the troika's ability to blame the crisis on nation-states while leaving the Eurozone monetary system untouched. In Spain, the model of austerity surveillance reached the general public through various narratives, particularly those portraying citizens who han vivido por encima de sus posibilidades (had lived beyond their means) due to "a cultural curse associated with the Spanish character, preventing them from becoming true Europeans" (Alonso, Fernández Rodríguez, and Ibáñez Rojo 2016, 25). In such a context, where all Spaniards are guilty of excess, surveillance discourses attracted a significant audience, finding supporters across the social and political spectrum. At the hospital, for instance, clinicians often remarked on the lack of the oversight of trading as the most pressing problem for timely diagnosis and treatment.

In diagnosing traders with gambling disorder, clinicians in Barcelona employed the fourth edition of the Diagnostic and Statistical Manual of Mental Disorders -DSM-4 for short (American Psychiatric Association 1994). This checklist approach to mental disorder already situated the activity of excessive gambling within the medical domain in its third edition, published in 1980 (Castellani 2000). The DSM-3 constituted the first step toward what came to be known as the medical model of gambling. The category of pathological gambling, as it appeared in the DSM-3, placed the diagnostic emphasis on debt and fraudulent financial operations. ${ }^{10}$ However, this list of symptoms had a relatively short life because “diagnosis was too often misused as an insanity defense” (Castellani 2000, 54). Although the DSM-4 erased the idiom of debt from the diagnostic criteria, the tension between the medical and the legal over debt liability remained. As Nuria intimated to me, "when I served as expert witness in Silvia's trial, the plaintiff lawyer kept discrediting my report because, according to him, I was trying to help Silvia's defense. I had to request the judge to put on record that I was a public servant summoned by the court and not an expert witness for hire."

David Graeber (2011) offers us insight into the friction between mental health and criminal law around issues of debt. In his view, discourses of debt turn violence into numbers in order to moralize otherwise exploitative and oppressive relationships between creditors and debtors. In Spain, clinical diagnosis and criminal litigation constitute competing yet mutually imbricated ways of defining debt liability. Spanish jurisprudence, for instance, has recognized pathological gambling as a mitigating circumstance since the early 1990s, but the Código Penal (criminal code) does not include it explicitly. This legal void makes the dictamen pericial (expert report) a decisive factor in mitigating the conviction of guilt for fraud and other financial offences (Echeburúa Odriozola, Amor Andrés, and Yuste 
García 2000). ${ }^{11}$ From this vantage point, the disappearance of debt and debtrelated notions from the gambling section of the DSM-4 suggests an ongoing struggle between psychopathology and criminology over which framework regulates the relationship between creditors and debtors.

During the period of my fieldwork, another tension between the medical and the legal came to light. The DSM-4 was to be replaced with a new edition of the manual in May 2013. ${ }^{12}$ The DSM-5 removed the criterion of "illegal acts" from the list of symptoms. Some psychiatrists saw this as a step forward because it detached diagnosis from crime. Others disliked it precisely for that reason. As Peter Conrad (1992, 218) would have it, the debate revolved around the pros and cons of having a "medical-legal hybrid." For instance, Nuria considered the elimination of illegal acts from the diagnostic criteria to be "important but not determinant." She recalled that Silvia met that specific criterion but also presented "more significant" symptoms such as "lack of risk calculation" and "high levels of sensation-seeking." Nuria remarked that the new checklist reduced the threshold for diagnosis from five to four symptoms, which balanced out the missing one. In her view, illegal behavior was a consequence of severe gambling disorder rather than a diagnostic symptom. The illegal-acts criterion in the DSM-4 included "forgery, fraud, theft, or embezzlement to finance gambling" (American Psychiatric Association 2000, 674), and was introduced as a diagnostic criterion to establish a clear distinction between pathogenic elements and ensuing gambling-disordered behaviors (see also Granero et al. 2014). Most clinicians recognized that the recalibration of diagnosis could affect the legal definition of gambling. However, no one had a clear picture of how this would unfold, given the limited research on the subject.

One shortcoming of Graeber's theorization of debt is that it fails to take into account those whom Gustav Peebles $(2013,712)$ calls "inveterate debtors." In a series of articles about credit and debt regulation throughout Europe and the United States, Peebles (2012, 431; see also 2013) addresses what he calls "the dialectic development of debt-evasion and debt-forgiveness" over a period of two centuries. He examines various legal infrastructures such as the debtors' prison, bankruptcy law, and offshore havens to show how debt evasion and debt forgiveness feed one another in suspending, or even eliminating, debt liability. His analysis challenges Graeber's theorization in shifting emphasis away from structural violence to individual agency, and by doing so, brings into view the options available to debtors, whose failure in the stock market forces them to seek out a respite from the suffocating everydayness of debt default. Peebles's approach to 
the debtors' prison and other spaces outside exchange sheds light on a key aspect of the clinical economy of speculation, that is, the potential to use one's pathologized status to fend off creditors for some period of time and, in certain cases, to evade incarceration. ${ }^{13}$

Graeber and Peebles help us recognize the stakes of debt and the alternatives for debtors. However, both overlook the transformation of debt into a means of profit. As Fiona Allon $(2015,702)$ puts it, "these are 'debts' that exist as much more than a simple sense of obligation or liability: the commodification of debt in securitized financial instruments facilitates ever-growing webs of profit-generating interconnection." In the next section, I depict the clinical economy of speculation from Silvia's point of view to show how the commodification of debt imposes new challenges on the clinical understanding of problem gambling. I focus on a single trader to underscore the phenomenological interplay of debt, trading, and gambling. Like Hirokazu Miyazaki's (2006) ethnography of Tada's dreams, which shows us Japanese traders' hopeful quest for meaning and profit, Silvia's story makes apparent the liminality of freelance trading in Spain. ${ }^{14}$

\section{BECOMING A BOLSERA THROUGH ON-SCREEN MARKETS}

According to the terminology of the European Securities and Market Authority (ESMA; 2016, 4), Silvia was a "retail client" who "speculate[d] on the short-term movements in the price of financial instruments." Like most freelancers, Silvia traded online in CFDs, an abbreviation of "contracts for difference," financial agreements between buyers and sellers to profit from price variations (Loussouarn 2013). ${ }^{15}$ In 2013, ESMA issued an official warning about CFDs in response to the mass marketing of this financial instrument since the beginning of the financial crisis. The document alerted retail clients to the dangers of speculation and leverage (ESMA 2013). In the late 2000s, when Silvia became a freelance trader, the stock-market retail sector was still embryonic, so the assortment of online trading platforms was not as broad as it was only a few years later when I entered the field in 2011. As Silvia and other freelance traders explained to me, most people signing up for online platforms at the time came from investment clubs within the Barcelona Stock Exchange, which had an atmosphere more amateurish than professional, like a game before it became a sport. ${ }^{16}$ Silvia became involved in trading at a young age. After college, she had landed a job in a local bank as assistant account manager. For years, she occupied the workstation closest to a cream-white wall in a row of cubicles adjacent to a marble counter. Silvia liked the coziness of the place, its studied unpretentiousness, and most of all, as 
she said, "the very fact that it was my first paid job ever." Her branch hosted Silvia's first encounter with her trading mentor, a seventy-five-year-old local businessman who approached stock trading as a pastime. "He was among the richest people in my town," Silvia emphasized. This trading hobbyist taught Silvia the nuts and bolts of financial markets and gave her a handful of tricks with which to start speculating.

Five years later, Silvia was relocated to the bank's headquarters in Barcelona. She was appointed sales trader in charge of retail clients. This time, her workspace was a standard small office with an eighth-floor view; like any other located in an edifice with bottomless elevators, it was sleek and soulless. Silvia joined the investment division during the rise of the housing bubble, which propelled the Spanish economy to grow around 5 percent each year between 1998 and 2000 (López and Rodríguez 2011). This was a time when the Spanish banking industry was busy catching up with American-style financial engineering in the context of market deregulation brought on by the creation of the eurozone (Palomera 2015). As Irene Sabaté (2016) argues, through the process of titulización (securitization), Spain replicated the U.S. subprime mortgage model. Securitization, in this context, meant to slice and dice mortgages into debt-freight bundles of assets to be sold to swaths of investors worldwide. On the ground at the time, Alberto Corsín Jiménez (forthcoming, 3) depicted the “emotional exuberance” of Spain’s mortgage momentum as an affective mix of confidence, optimism, and greed. This heady mix contributed to the "in-construction" character of urban geographies and cityscapes across Spain in those years.

The exuberance came to an end in 2007, when the Spanish financial system was smashed flat by the burst of the housing bubble. That year, an Italian financial group bought the bank where Silvia worked. Silvia disliked the new management and, as Karen Ho (2009) might put it, Silvia had reached the gender ceiling of high finance, which in Spain included not only the higher echelons of the banking ladder but also the trading floor. Under these circumstances, Silvia negotiated a layoff package and took with her a thick address book of clients (see Lépinay 2011). She returned to her hometown to set up shop as a freelance trader. In the following months, Silvia did well on the market and her confidence grew. She had rearranged her home to have her workstation next to a guest bathroom and an area where she could meet with clients. However, this adjustment left her two-bedroom apartment without a dining room. Her workstation occupied the whole space with a carapace of screens and a laptop surrounded by piles of newspapers. Silvia had turned her home into a trading room that extended her 
life into two bodies, which were not always in concert (see Lépinay 2011). On the one hand, she became a chiringuito (unlicensed broker). ${ }^{17}$ On the other, she lived in a digital landscape where she interacted with the market. In her research with financial traders, Karin Knorr Cetina (2014, 129) conceptualizes trading floors as "attentional regimes" in which on-screen markets surround traders to enhance their focus and create the illusion of the market as a robust reality. In her view, trading floors supply the institutional and organizational means for traders to become enthralled by market flows. From a somewhat different perspective, Caitlin Zaloom (2014) juxtaposes trading rooms and casino floors to compare the daily work of financial traders with the experience of machine gamblers. In a rich, cross-pollinating dialogue with Natasha Schüll (2012), Zaloom argues that financial traders, like machine gamblers, seek out the zone- a technologically engineered mind-state of complete absorption through which money becomes temporarily detached from conventional circuits of value. Like casinos, trading rooms constitute an enclosed world where traders "lose any sense of space, time, and self" (Zaloom 2014, 179).

This scholarship resonates deeply with the experience of freelance traders in Barcelona. These traders also stitch their attention to on-screen markets, unflaggingly tracking prices that yo-yo up and down in psychedelic colors. They too develop trading habits around idealized states of awareness. Silvia, for her part, lived in a quiet neighborhood near a park, but rarely left her apartment to wander. Her routine was carefully organized around the opening and closing times of the German and Spanish stock exchanges. She woke up very early in the morning, had breakfast, read every single financial newspaper, and sat at her workstation. By 9 a.m. she was placing her first round of trades. A couple of hours later, depending on what was going on with her trading orders, she took a short break to make phone calls and reply to emails, often communicating with her clients and her broker while drinking cup after cup of coffee to keep her mental processes in motion. She took another break at noon and did not resume her on-screen activity until 4 p.m. for the closing session, when markets "gave [her] some game again." As Silvia noted, underscoring the rigor of her timetable, "I had to schedule my meals and snacks - otherwise I forgot to eat.”

Silvia recalled that her trading behavior became more erratic and sloppier with time. "I started acting like a bolsera," she said. In Spanish market argot, the label bolsero/a has negative social and behavioral connotations. It indicates lower class status, on the one hand, and an almost irrational approach to financial markets, on the other. Bolseros are not difficult to recognize in Spain. They are mostly 
middle-aged men who take high risks on a daily basis, setting them aside from the majority of small investors, who are long-term, risk-averse clients in a stilldeveloping retail market. According to the Banco de España's $(2014,83)$ Family Financial Survey of 2011, only 11 percent of households owned tradable securities, of which 30.7 percent belonged to higher-income families with heads of household between fifty-five and sixty-four years old. Their average investment fluctuated between seven and ten thousand euros.

The term bolsero was also employed to emphasize financially unsound behaviors. As one sales trader told me, "I have clients who have lost everything on the market and kept on trading with their unemployment benefits or even by getting personal loans." During my fieldwork, I attended more than a dozen of mesas de trabajo (teach-ins) for freelance traders. At these events, I observed how sales traders opposed the term bolsero to the Anglicism trader in an attempt to detach some of the negative attributions that went along with stereotypes surrounding bolseros, particularly their association with gambling. Jugar a la bolsa, which in Spanish literally means to gamble on the stock market, was a common expression among freelance traders in accusing each other of acting irresponsibly.

My interlocutors disliked the label bolsero, except when they used it of themselves to underscore their disadvantageous position vis-à-vis institutional traders. An alternative hermeneutic horizon for the term bolsero, however, "stitch[ed] together specific moments in time, paying little attention to temporal distance" (Knight 2016, 34). This other interpretation of freelance trading was less tainted by marketing, and yet it also evoked fears of gambling. As an experienced trader pointed out, freelance trading had been associated with gambling since the very inception of stock exchanges in Spain. Drawing on Daniel Knight's (2016) analysis of the multiple temporalities of crisis in Greece, in the following section I explore early associations of trading and gambling to highlight how certain moments of the past remain relevant and proximate in providing a sense of direction to people and institutions. In doing so, I reveal a deeply rooted antigambling ideology that reverberates within the medical model of trading today.

\section{HISTORIES OF DEBT AND STOCK-MARKET GAMBLING}

In her analysis of leverage in the world of hedge funds, Marieke de Goede $(2005,48)$ argues that "the ambiguity between credit practices and gambling . . . has been a recurrent debate that has shaped the laws and institutions of modern finance." For de Goede, credit has been the underbelly of a prolonged politico- 
legal struggle to separate gambling from finance as two distinct modes of speculation. Indeed, in the United States and the United Kingdom, speculation constitutes a longstanding gray area between bets and trades. Ann Fabian (1990) has shown that gambling metaphors helped nineteenth-century moral reformers in the United States to imagine a dystopian economy run by devious speculators whose actions harmed society as a whole. In conversation with Fabian, Pat O'Malley (2004) claims that it was commercial law rather than morality that made thinkable the separation of gambling from finance in the United Kingdom. In Spain, gambling has rarely been perceived as a valuable activity. The dictator and prime minister Miguel Primo de Rivera banned it in 1928, and the ban remained in effect throughout the Second Republic and until the fall of Francisco Franco's dictatorship in 1975 (Gómez Yañez et al. 2014). Spanish debates over gambling and finance in the nineteenth century, however, dealt neither with morality nor commercial law, but instead with the governance of public debt (Rojo Cagigal and Houpt 2011).

In the United States of the nineteenth century, gambling was a morally denigrated transaction. In the United Kingdom, gambling constituted a legal conundrum. Spanish lawmakers of the same period saw gambling as a mal necesario (necessary evil), which could threaten the nation-state if not kept in check. Speculation was not "an uneasy middle ground" (de Goede 2005, 48) between gambling and finance, but part of a nested structure in which gambling, speculation, and finance were placed one inside the other like a Russian doll. Any element of the triad could evolve into a danger for a nation-state that was (and still is) constantly defending itself against the threat of secession. Catalonia's pro-independence movement, with its focus on economic issues, is but a convenient example of the never-ending struggle over political and financial control between the central government and the most economically developed regions of the country (McDonogh 1986; Pujadas 2013; Crameri 2014). ${ }^{18}$

In 1831 Pedro Sainz Andino drafted the first Spanish Stock Exchange Law, replicating a state-centered French model more concerned with governance than commerce. This legal framework understood stock exchanges as a hinge between public and private interests, which were to be balanced by the state. In an 1845 essay, Andino complained about unscrupulous speculators who had turned financial markets into casinos, making reference to unregulated stock exchanges in such major cities as Barcelona (Bermejo Cabrero 1997). As Jaime Vicens Vives (1969) explains, Catalonia's rapid industrialization and railway construction allowed it to develop its own financial institutions, including the establishment in 
1840 of a self-regulated stock-exchange system. This evolved into Barcelona's Stock Exchange in 1912, which remained operational until the Spanish Civil War (1936-1939), resisting repeated efforts at financial unification.

More recently, Jaime Palomera $(2015,4)$ has argued that Catalan capitalism emerged from the industrial revolution of 1830, when "new steam factories and colonies configured a model of small and medium-scale development mostly based on textile production - cotton in particular - and other industries such as leather and paper." During this period, Juan Carlos Rojo Cagigal and Stefan Houpt (2011) have traced the creation of a new profession within finance: the agente de cambio (exchange agent), a literal translation of the French term agent de change. According to Rojo Cagigal and Houpt, the professionalization of trading had a clear political purpose: keeping freelance traders away from public debt. For Spanish lawmakers like Andino, freelance traders represented the opposite of public interest, and public debt and public interest were interchangeable concepts. Freelance traders were necessary middlemen to keep the system in motion. Yet they were also dangerous "stock market gamblers" (Bermejo Cabrero 1997, 1820). Nonetheless, Barcelona's stock exchanges never deterred freelance traders from dealing in public debt or in any other sorts of transactions. Freelance traders populated outcry pits without restriction, even if they were acting outside the law. Ultimately, these traders succeeded in breaking up the monopoly that official brokers held in the Spanish state.

This historical detour is relevant because the temporal distance between professionalization and the pathologization of trading makes apparent the processes of figuration (see Weston 2013) through which an ideal freelance trader comes to life within the Spanish financial system. The Spanish bolsero, like the Manchester worker or the Wall Street banker, offers a convincing protagonist for the narratives of capitalism (Appel 2014, 53). Indeed, the freelance trader has been the exemplary figure around which the lines of proper speculation have been drawn throughout Spain's history. What marks off the present time is the way in which these lines are established through clinical practices rather than bureaucratic certificates.

Building on Anna Tsing's treatment of capitalist endeavors as imaginative projects, Hannah Appel (2014) calls attention to the gendered and racialized nature of these figurations of finance. The figure of the Spanish bolsero offers a case in point: a white male who "at least partially allows finance a narrative wholeness unmarked by difference and exclusion" (Appel 2014, 53). In the last section of this article, I focus on how the paradigm of the problem gambler offers 
traders a zone of debt evasion and forgiveness, but in doing so, confines women to the household economy and the traditional role of caretaker, thus contributing to their exile from the heights of finance.

\section{LEVERAGING PROBLEM GAMBLING: Speculation and Gender}

By 2009, Silvia was accepting quasi-deposits from clients. "I traded on their behalf in exchange for a small commission," Silvia said, explaining her financial scheme. Unlike institutional traders who followed a game plan (Lépinay 2011) and whose losses were covered (Zaloom 2014), Silvia's job was to shoulder the risks of speculation while milking the market on a daily basis, suffering firsthand the attendant consequences of her mistakes. "Me apalanqué demasiado [I leveraged too much]. That was my problem," she said in introducing the beginning of her failure. She had her first major setback during the summer of 2010, when she cashed out her mother's retirement savings to weather the storm and buy herself some time, making it last long enough to avoid a panic run of clients. "I thought I'd be able to recuperate my mother's money soon. But things started to fall apart," Silvia said. This was not the only time Silvia sacrificed familial wealth to keep her business afloat. A few months later, Silvia's business was without liquidity again. This time her sister was dragged into one of her lawsuits, because she was the co-owner of a piece of real estate that Silvia had used as collateral to access cash. After that, Silvia struggled for several months, but was never able to recover. Following the first lawsuit, many others started to pile up.

"Her sister sent me a desperate email requesting an urgent appointment. Silvia had made a gesto autolítico [suicidal gesture] during a fight with her," said Nuria, in recalling how Silvia became her patient. "According to her sister, Silvia rushed toward a window to jump out." By then, Silvia had begun treatment at a clinic in her hometown, but "she did not feel comfortable with the doctor," Nuria said. It was not until several months after her bankruptcy that Silvia started treatment at CUH. At the time, she was unemployed and had five lawsuits pending against her. "Silvia was in very bad shape during our first appointment," Nuria recalled. Silvia and Nuria became very close. "We continue to meet every week for therapy, even though she has been 'officially' discharged. She says she doesn't have anyone to talk to,” Nuria told me the last time we spoke in 2015.

The way Silvia engaged with therapy is arguably a form of leveraging problem gambling. Initially, she resisted medicalization. "Silvia is not completely conscious of her gambling problem," Nuria said during our first formal interview. "Other patients accept that they are addicted to trading, just like a drug user develops 
an addiction to cocaine or any other substance, but Silvia continues to tell me her problem was lacking enough money to stay in the market." Silvia remained ambivalent toward blame throughout much of her subsequent treatment. Even two years in, Nuria told me, "Silvia feels bad for those who lost their savings, but not so much for those who knew the stakes. She thinks those people are rich anyway, so they don't need the money." In the end, however, Silvia came to accept her clinical personification, and in doing so, found ways to take advantage of being a pathologized trader. For instance, Nuria became instrumental in helping her to cope with the aftermath of bankruptcy, not only as a medical expert in pending lawsuits but also as a peacemaker in family squabbles. Nuria spoke regularly with Silvia's sister about her patient's behavior. "When Silvia has any problem with her sister, she asks me to talk to her. She uses me as a channel of communication with her family," said Nuria, reflecting on how "well-adjusted to therapy" Silvia had become with time. "She hasn't missed a single visit in all these years," Nuria added.

Recall that Gustav Peebles (2012) conceptualizes debt evasion and forgiveness as zones outside of exchange, where insolvent debtors find a sanctuary from market demands. As Peebles $(2012$, 440) puts it, "debt forgiveness and debt evasion need to be seen as providing the debtor with two different modes of freedom. Debt evasion provides freedom from the domestic credit and debt system in exchange for the loss of freedom of movement, while debt forgiveness lashes one back into the credit and debt system in exchange for continued freedom of movement." In this light, Silvia's status as a problem gambler has indeed offered her a small space in which to organize her life and deal with financial failure.

However, compared to Peebles's $(2013,712)$ depictions of the debtors' prison, where "by day, prisoners played squash and gambled, prior to singing and carousing at night," Silvia's daily life was suffocating, laborious, and lonely. When I met her, she did not have a bank account, which made it impossible for her to manage basic utility bills by herself. She had moved in with her mother and had become her main caretaker. She was economically dependent on her siblings, and her sister had her under strict monetary surveillance. Silvia's everyday life was a sort of training camp for the actuarial self, as Natasha Schüll $(2012,247)$ describes "the calculative self-inspection that gambling addicts are encouraged to undertake." All her expenditures were evaluated and approved by a family member. She had to justify all of her outings and purchases, even mundane little things. “Sometimes I don't see a euro for weeks," Silvia told me. She had only sporadic access to a computer and the Internet, because "the markets are online," as she 
put it. She took care of her elderly mother around the clock, and accompanied her sister to buy groceries. She cleaned the house and watched over her nephews without compensation. Silvia felt alone: "I have three friends left who don't even come to visit me at home. Whenever we want to meet, we do it at the beach in Barcelona, almost in hiding. They don't want to be seen with me in public."

Silvia perceived domestic labor as a way to make amends for her actions, "to pay back what I took away from my family," as she phrased it. Yet she hated housework. Her former home looked like an office. In Nuria's words, "For many years, Silvia lived the life of a high-ranked executive in Barcelona." What Nuria had in mind with this depiction was the figure of a male banker during the years of the financial bubble. This and other gendered constructions of finance infused the clinical imagination of trading in Spain. Thus, when I spoke with Nuria about gender differences in problem gamblers and traders, she characterized Silvia as "an independent, self-attentive, self-sufficient woman, who likes to play the dominant role, to make more decisions." According to the psychopathology of gambling, Nuria indicated, men and women differ. Women "start to gamble later to regulate negative emotional states, and not to obtain the gratification or excitement that winning entails," Nuria told me. "If we think [in terms of] stereotypes, Silvia behaves more like a man than a woman. She has a more masculine profile . . her interpersonal relationships and her relations with male partners make me think she's an unconventional woman. She doesn't want a long-term partner. In fact, she's never had one and she doesn't want children." I asked Nuria if her male patients also saw the household as a space for redemption. They did not, Nuria said. Most looked for a job while in treatment and tried to stay occupied, often with sports.

There are many ways to interpret Nuria's remarks. For the purposes of this article, I focus on what Nuria characterizes as masculine in order to highlight that Silvia had lost precisely her capability to be an "independent, self-attentive, selfsufficient woman, who likes to play a dominant role [and] make more decisions." The problem-gambling model offered Silvia sanctuary - but at a very high price. In exchange, she had to accept the female gender role of caregiving, which she had never wanted or appreciated. Compared to Peebles's prisoners, Silvia had to give up more than her freedom of movement to get a respite from indebtedness. She had to comply with the gendered figurations of contemporary capitalism. Why? Because Silvia embodied the antithesis of the good wife mentioned previously, and therefore represented a double danger to the politics of finance (Bras- 
sett and Rethel 2015). Silvia was not only an insolvent trader; she was a woman insolvent trader.

Attention to gender corrects a serious problem with the long-term view of credit and debt - its tendency to create a totalizing illusion of capitalism (GibsonGraham 2014; Bear et al. 2015). To avoid characterizing the clinical economy of speculation as a pathologized area of speculative finance, I have traced Silvia's story over time and across places. In doing so, I have depicted the clinical encounter between Silvia and Nuria as a medico-financial project around which new lines of proper financial speculation were being drawn. As Anna Tsing (2000) might put it, the clinical economy of speculation is a scalar endeavor with its own concrete sites of encounter and definitional struggles. Silvia's story thus offers one way of showing how "small facts" speak to "large issues" (Gibson-Graham 2014, 148), namely the postcrisis regime of credit and debt surveillance.

In this article, I have made the case that the clinical economy of speculation represents an extension of European financial discourses meant to control credit and debt relations in postcrisis Spain. In doing so, I have depicted how the market manifests itself in social phenomena beyond its traditional financial configurations. More specifically, I have suggested that diagnosing traders with gambling disorder has become a constitutive practice in terms of what we know and perform as the market. At stake here is the capacity of financial markets to penetrate into our daily lives in multiple ways and forms. In this light, the DSM-5's treatment of gambling disorder sets both diagnostic and regulatory guidelines for the improper and proper management of credit and debt. A psycho-juridical approach to finance, I argue, can help us to observe societal dynamics that are simultaneously the market and something else. ${ }^{19}$

I have also argued that the medicalization of trading illustrates how the master trope of gambling still operates in Spain through the figure of a necessary evil that lurks at the margins of stock exchanges. I suggest that nineteenth-century gambling metaphors have reappeared in the Spanish context to draw new lines around proper financial speculation. This time, however, instead of public debt and its politico-legal associations with the public interest, what generates and activates control mechanisms within the market is the effect of financial leveraging on mental health. The medical model of leverage control serves as evidence of the manner in which gambling metaphors continue to scaffold a particular mode of accumulation based on credit and debt. Moreover, the pathologized trader embodies the impropriety of the overindebted subject, one who inhabits the expanding medical space of debt evasion and debt forgiveness. ${ }^{20}$ 
Finally, I have highlighted gender inequalities within the field of trading to show that credit and debt are not neutral financial instruments. The gendering of finance is key to understanding the generative aspects of capitalism without turning the market into a determining structure or an unmediated calculative device. In my view, the market is multiple and heterogeneous, inflecting perceptions of the real beyond economistic renderings of social dynamics (see Bear et al. 2015). From this perspective, Silvia's experience as a freelance trader does not end with her being diagnosed with gambling disorder. On the contrary, as a pathologized trader she begins to transit uncharted territories of finance, where certain transactions of credit and debt are perceived as symptoms of mental disorder.

To conclude, I believe that the clinical economy of speculation offers an alternative hermeneutic horizon through which to view Silvia's actions historically and politically, rather than as intrinsically antisocial and irrational. This is particularly important in a country like Spain, where the Great Recession has bred more new millionaires than ever before, with bankers and politicians dodging corruption scandals by claiming to have made their riches in trading and investing. At the same time, individuals like Silvia, who represent the smaller fish of the economy, are being medicalized and sometimes even incarcerated.

\section{ABSTRACT}

This article concerns itself with financial traders in Spain who have been diagnosed with gambling disorder. It analyzes what I call the clinical economy of speculation, in which the category of problem gambler is repurposed to draw new lines around proper financial trading. In exploring the expansion of post-financial crisis regulatory mechanisms for credit and debt, as well as widening inequalities across the field of investment, I depict how both traders and clinicians become invested in medicalizing trading as gambling disorder. My theorizing interrogates whether and why common speculative practices are seen as sick and unsafe when everyday people, instead of banks and other financial institutions, perform them. I argue that the pathologized trader is an attempt to regulate, at the individual level, the increasing use of borrowed capital to make financial profits. The commodification of debt, however, is not a gender-neutral development. Female traders pay a greater price for venturing into the heights of finance. This focus on gender brings into view the redefinition of credit and debt within the domain of trading, and shows the role of debt-fueled financial speculation in the expansion of financial markets. These ethnographic findings are particularly relevant in a country like Spain, where the Great Recession has bred more new millionaires than ever before, even as the smaller fish of the economy are being medicalized and sometimes even incarcerated. [financial trading; gambling disorder; Great Recession; Spain] 


\section{NOTES}

Acknowledgments I am deeply grateful to Silvia for sharing her story with me, and to Nuria for her trust and engagement with my ethnography. For my approach to theorization I am indebted to my dearest friend and mentor, Alan Klima. I want to express my gratitude to Joe Dumit, Cristiana Giordano, Jim Smith, Smriti Srinivas, and Joan Pujadas for their continuous advice and useful comments. For their generous feedback on previous drafts, I thank Maka Suarez, Rebecca Cassidy, Salomon Cuesta, Natalia Buitron-Arias, Gregory Deshoullière, Laura Meek, and Jennifer Fleetwood. I am also very grateful to Susana Jimenez-Murcia, Juan Carlos Uríszar, Monica Martinez, Montserrat Clua, Marta Ausona, and Eduardo Kingman. Their help and support in the field were invaluable. I thank Mateo Martínez and Milton Reyes for their ideas and interest in my work. This essay greatly benefited from the insightful comments of three anonymous reviewers and the editorial collective at Cultural Anthropology, particularly James Faubion. Grants from the Wenner-Gren Foundation and the National Science Foundation supported my fieldwork in Barcelona.

1. I use pseudonyms for all my respondents and have changed some personal details to conceal identities. Unless otherwise indicated, phrases in quotation marks are my translations from interviews conducted in Spanish. Finally, I have changed or omitted names of institutions and businesses for the purposes of anonymity.

2. I use the term financial trader as a general category that includes institutional and freelance traders. I translate the term gestor de cartera as sales trader, and both bolsero/a and the Anglicism trader autónomo as freelance trader.

3. In February 2017, Rodrigo Rato was convicted for embezzlement and sentenced to four and a half years in prison.

4. Stock-market investment patient is a clinical term used by Spanish clinicians in Englishlanguage publications.

5. Machine gambling was legalized in Spain in 1981.

6. In 2011, all forms of gambling expenditure decreased except for online gambling.

7. Nuria's research sample relied on data regarding eighteen patients with trading as a primary gambling problem and seventy-six patients with trading as a secondary gambling problem.

8. Silvia gave Nuria explicit permission to discuss her case with me. Both Silvia and Nuria agreed that Silvia was capable of consent in this capacity.

9. Postprogram surveillance was implemented in Spain to oversee the Financial Sector Adjustment Program of 2012. The last review was issued in 2016 (European Commission 2016).

10. Five of the seven diagnostic criteria in the DSM-3 made reference to monetary mismanagement. In this edition, anyone who met three or more criteria was diagnosed with pathological gambling.

11. The dictamen pericial (expert report) is a comprehensive clinical diagnosis for the judge to consider in her ruling.

12. The DSM-5 replaced the term pathological gambling with disordered gambling and relocated it from the category of impulse control into the category of addiction (Schüll 2012, 324). As my research respondents did during my fieldwork, I use pathological gambler and disordered gambler interchangeably.

13. A gambling disorder is a mitigating circumstance. In certain cases, depending on the judge, it can prevent imprisonment.

14. A more recent example of a study structured around a single subject in the social studies of finance is Marieke de Goede's (2015) analysis of the trial for securities fraud of former Goldman Sachs employee Fabrice Tourre.

15. CFDs are highly leveraged products; traders never actually buy or own the underlying asset. They make a profit from the difference between the purchasing price and the price at the time of selling. These transactions take place over very short periods of time, less than one day (ESMA 2013).

16. Investment clubs usually had less than fifty members and each participant could not 
invest more than €12,000. The Barcelona Stock Exchange went from having 1,500 investment clubs in the 1980s to 278 in 2005.

17. Chiringuito is a colloquial term for unlicensed brokerage firms. They were a high-priority concern for the Comisión del Mercado de Valores (2012), which published a booklet on the issue aimed at the general public.

18. I do not engage with Catalonia's pro-independence movement here, due to space limitations. Elsewhere, I have written about the relationship between public debt and Catalan nationalism (Núñez 2017).

19. The need to pay attention to things that are simultaneously a market and not a market was eloquently articulated by Bill Maurer at the 2016 annual meeting of the American Anthropological Association, during a session entitled "Offshore Economies: New Markets, New Pressures, New Questions.” My argument strongly resonates with Maurer's commentary on the copresence of the market inside and outside economistic renderings.

20. I thank James Faubion for his insightful comments in this context on the all-too-material metaphoricity of discourse.

\section{REFERENCES}

Allon, Fiona

2015 “Everyday Leverage, or Leveraging the Everyday.” Cultural Studies 29, nos. 56: 687-706. https://doi.org/10.1080/09502386.2015.1017140.

Alonso, Luis Enrique, Carlos J. Fernández Rodríguez, and Rafael Ibáñez Rojo

2016 "Entre la austeridad y el malestar: Discursos sobre consumo y crisis económica en España.” Revista Española de Investigaciones Sociológicas, no. 155. https:// doi.org/10.5477/cis/reis.155.21.

American Psychiatric Association

2000 Diagnostic and Statistical Manual of Mental Disorders. 4th edition, text revision. Appel, Hannah Washington, DC: American Psychiatric Association.

2014 "Finance, Figuration, and the Alternative Banking Group of Occupy Wall Street." Signs 40, no. 1: 53-58. https://doi.org/10.1086/676893.

Banco de España

2014 "Encuesta Financiera de las Familias (EFF) 2011: métodos, resultados, y cambios desde 2008.” Boletín Económico, January: 71-103.

Bear, Laura, Karen Ho, Anna Tsing, and Sylvia Yanagisako

2015 "Gens: A Feminist Manifesto for the Study of Capitalism." In "Generating Capitalism," Theorizing the Contemporary series edited by Laura Bear, Karen Ho, Anna Tsing, and Sylvia Yanagisako, Cultural Anthropology website, March 30. https:/ / culanth.org/fieldsights / 652-gens-a-feminist-manifesto-for-the-studyof-capitalism.

Bermejo Cabrero, José Luis

1997 "Sainz de Andino y los orígenes de la bolsa de Madrid." Anuario de historia del derecho español, no. 67: 1813-24. https://dialnet.unirioja.es/servlet/articulo? codigo $=134679$.

Biehl, João, and Amy Moran-Thomas

2009 “Symptom: Subjectivities, Social Ills, Technologies." Annual Review of Anthropology 38: 267-88. https://doi.org/10.1146/annurev-anthro-091908-164420.

Brassett, James, and Lena Rethel

2015 "Sexy Money: The Heteronormative Politics of Global Finance." Review of International Studies 41, no. 3: 429-49. https://doi.org/10.1017/ S0260210514000461.

Cassidy, Rebecca, Claire Loussouarn, and Andrea Pisac

2013 “Fair Game: Producing Gambling Research.” Research report, Goldsmiths, University of London. http://www.gold.ac.uk/gamblingineurope/report. 
Cassidy, Rebecca, Andrea Pisac, and Claire Loussouarn, eds.

2013 Qualitative Research in Gambling: Exploring the Production and Consumption of Risk. New York: Routledge.

Castellani, Brian

2000 Pathological Gambling: The Making of a Medical Problem. Albany: State University of New York Press.

Charnock, Greig, Thomas Purcell, and Ramon Rivera-Fumaz

2014 The Limits to Capital in Spain: Crisis and Revolt in the European South. New York: Palgrave Macmillan.

Comisión Nacional del Mercado de Valores

2012 "Los chiringuitos financieros." Informational guide, Oficina de Atención al

Conrad, Peter Inversor. https://www.cnmv.es/portal/Publicaciones/Guias.aspx.

1992 “Medicalization and Social Control." Annual Review of Sociology 18: 209-32. https://doi.org/10.1146/annurev.so.18.080192.001233.

Corsín Jiménez, Alberto

Forthcoming “Mortgage Durée: Towards a Politics 'In Construction."” Published online September 5, 2016. Ethnos. https://doi.org/10.1080/00141844.2016.

Crameri, Kathryn 1220968.

2014 Goodbye, Spain? The Question of Independence for Catalonia. Eastbourne, U.K.: Sussex Academic Press.

Crowley-Matoka, Megan, and Gala True

2012 "No One Wants to Be the Candy Man: Ambivalent Medicalization and Clinician Subjectivity in Pain Management.” Cultural Anthropology 27, no. 4: 689-712.

Davis, Elizabeth https://doi.org/10.1111/j.1548-1360.2012.01167.x.

2010 “The Antisocial Profile: Deception and Intimacy in Greek Psychiatry." Cultural Anthropology 25, no. 1: 130-64. https://doi.org/10.1111/j.1548-1360.2009. 01054.x.

2015 “'We've toiled without end': Publicity, Crisis, and the Suicide 'Epidemic' in Greece.” Comparative Studies in Society and History 57, no. 4: 1007-36. https:// doi.org/10.1017/S0010417515000420.

De Goede, Marieke

2005 Virtue, Fortune, and Faith: A Genealogy of Finance. Minneapolis: University of Minnesota Press.

Echeburúa Odriozola, Enrique, Pedro Javier Amor Andrés, and J. Yuste García

2000 "Atenuación de la responsabilidad penal en la ludopatía: Bases psicopatológicas." Psicopatología clinica legal y forence 1: 59-77.

European Commission

2016 "Financial Assistance to Spain." https://ec.europa.eu/info/business-economyeuro/economic-and-fiscal-policy-coordination/eu-financial-assistance/whicheu-countries-have-received-assistance/financial-assistance-spain_en.

European Securities and Market Authority (ESMA)

2013 “Contracts for Difference (CFDs).” Investor warning, February 28. Reference no. 2013/267. https://www.esma.europa.eu/investor-corner/warning-andpublications-investors.

2016 "Questions and Answers: Relating to the Provision of CFDs and Other Speculative Products to Retail Investors under MiFID.” Reference no. 2016/

Fabian, Ann 1165. https://www.esma.europa.eu/questions-and-answers.

1990 Card Sharps, Dream Books, and Bucket Shops: Gambling in Nineteenth-Century America. Ithaca, N.Y.: Cornell University Press. 
Fassin, Didier

2011 “This Is Not Medicalization.” In Drugs and Culture: Knowledge, Consumption, and Policy, edited by Geoffrey Hunt, Maitena Milhet, and Henri Bergeron, 85-93. Burlington, Vt.: Ashgate.

Garriott, William, and Eugene Raikhel

2015 "Addiction in the Making." Annual Review of Anthropology 44: 477-91. https:// doi.org/10.1146/annurev-anthro-102214-014242.

Gibson-Graham, J. K.

2014 "Rethinking the Economy with Thick Description and Weak Theory." Current Anthropology 55, no. S9: S147-53. https://doi.org/10.1086/676646.

Gómez Yañez, José Antonio, José Ignacio Cases Méndez, Germán Gusano Serrano, Carlos

Lalanda Fernández, and Ana Cases Comyn

2014 “Percepción social sobre el juego de azar en España 2014.” Instituto de Política y Gobernanza, Universidad Carlos III de Madrid.

Graeber, David

2011 Debt: The First Five Thousand Years. Brooklyn, N.Y: Melville House.

Granero, Roser, et al.

2014 "Contribution of Illegal Acts to Pathological Gambling Diagnosis: DSM-5 Implications.” Journal of Addictive Diseases 33, no. 1: 41-52. https://doi.org/ 10.1080/10550887.2014.882730.

Gregory, Chris A.

2012 "On Money Debt and Morality: Some Reflections on the Contribution of Economic Anthropology.” Social Anthropology 20, no. 4: 380-96. https:// doi.org/10.1111/j.1469-8676.2012.00225.x.

Han, Clara

2012 Life in Debt: Times of Care and Violence in Neoliberal Chile. Berkeley: University of California Press.

Ho, Karen

2009 Liquidated: An Ethnography of Wall Street. Durham, N.C.: Duke University Press. James, Deborah

2015 Money from Nothing: Indebtedness and Aspiration in South Africa. Stanford, California: Stanford University Press.

Kitanaka, Junko

2012 Depression in Japan: Psychiatric Cures for a Society in Distress. Princeton, N.J: Princeton University Press.

Klima, Alan

2006 “Spirits of 'Dark Finance' in Thailand: A Local Hazard for the International Moral Fund.” Cultural Dynamics 18, no. 1: 33-60. https://doi.org/10.1177/ 0921374006063414 .

Knight, Daniel M.

2016 “Temporal Vertigo and Time Vortices on Greece's Central Plain." Cambridge Journal of Anthropology 34, no. 1: 32-44. https://doi.org/10.3167/ca.2016. 340105.

Knorr Cetina, Karin

2003 "From Pipes to Scopes: The Flow Architecture of Financial Markets." Distinktion 4, no. 2: 7-23. https://doi.org/10.1080/1600910X.2003.9672857.

2014 "What is a Financial Market? Global Markets as Microinstitutional and Posttraditional Social Forms." In The Oxford Handbook of the Sociology of Finance, edited by Karin Knorr Cetina and Alex Preda, 169-86. New York: Oxford University Press.

Lépinay, Vincent Antonin

2011 Codes of Finance: Engineering Derivatives in a Global Bank. Princeton, N. J.: Princeton University Press. 
López, Isidro, and Emmanuel Rodríguez

2011 “The Spanish Model.” New Left Review, no. 69: 5-28. https://newleftreview. Loussouarn, Claire org/II/69/isidro-lopez-emmanuel-rodriguez-the-spanish-model.

2013 "Spread Betting and the City of London." In Qualitative Research in Gambling: Exploring the Production and Consumption of Risk, edited by Rebecca Cassidy, Andrea Pisac, and Claire Loussouarn, 233-49. New York: Routledge.

Maltby, Josephine, and Janette Rutterford

2014 "Gender and Finance." In The Oxford Handbook of the Sociology of Finance, edited by Karin Knorr Cetina and Alex Preda, 510-28. New York: Oxford University Press.

McDonogh, Gary W., ed.

1986 Conflict in Catalonia: Images of an Urban Society. Gainesville: University Presses of Florida.

Miyazaki, Hirokazu

2006 "Economy of Dreams: Hope in Global Capitalism and Its Critiques." Cultural Anthropology 21, no. 2: 147-72. https://doi.org/10.1525/can.2006.21.2.147.

2013 Arbitraging Japan: Dreams of Capitalism at the End of Finance. Berkeley: University of California Press.

Núñez, Jorge

2017 "Markets of Excitement: Debt, Speculation, and Catalonia." PhD dissertation, University of California, Davis.

O’Malley, Pat

2004 Risk, Uncertainty, and Government. London: GlassHouse.

Palomera, Jaime

2015 “The Political Economy of Spain: A Brief History (1939-2014).” Working paper for the European Research Council Greco Project. Departament d'Antropologia Social, Universitat de Barcelona.

Peebles, Gustav

2010 “The Anthropology of Credit and Debt.” Annual Review of Anthropology 39: 22540. https://doi.org/10.1146/annurev-anthro-090109-133856.

2012 "Whitewashing and Leg-Bailing: On the Spatiality of Debt." Social Anthropology 20, no. 4: 429-43. https://doi.org/10.1111/j.1469-8676.2012.00221.x.

2013 "Washing Away the Sins of Debt: The Nineteenth-Century Eradication of the Debtors' Prison." Comparative Studies in Society and History 55, no. 3: 701-724. https://doi.org/10.1017/S0010417513000297.

Pujadas, Joan J.

2013 "El debate sobre la autodeterminación de Cataluña: Dificultades de encaje de una nación minoritaria en un estado homogéneo.” Revista Ecuador Debate, no. 88:

Reith, Gerda 103-30. http://hdl.handle.net/10469/5407.

2007 "Gambling and the Contradictions of Consumption: A Genealogy of the 'Pathological' Subject.” American Behavioral Scientist 51, no. 1: 33-55. https:// doi.org/10.1177/0002764207304856.

Rizzo, James

2004 "Compulsive Gambling, Diagrammatic Reasoning, and Spacing Out." Public Roitman, Janet

Culture 16, no. 2: 265-88. https://doi.org/10.1215/08992363-16-2-265.

2013 Anti-Crisis. Durham, N.C.: Duke University Press.

Rojo Cagigal, Juan Carlos, and Stefan Houpt

2011 "Oneness versus Diversity in Legal and Economic Institutions: The Spanish Stock Markets, 1831-1936." Paper presented at the "Space and Place in Economic Growth" conference, Huntington Library, San Marino, Calif., April 22-23. 
Rosecrance, John

1985 "Compulsive Gambling and the Medicalization of Deviance." Social Problems 32, no. 3: 275-84. https://doi.org/10.2307/800687.

Sabaté, Irene

2016 "Mortgage Indebtedness and Home Repossessions as Symptoms of the Financialization of Housing Provisioning in Spain." Critique of Anthropology 36, no. 2: 197-211. https://doi.org/10.1177/0308275X15614636.

Schüll, Natasha Dow

2012 Addiction by Design: Machine Gambling in Las Vegas. Princeton, N.J.: Princeton University Press.

Stout, Noelle

2016 “\#Indebted: Disciplining the Moral Valence of Mortgage Debt Online." Cultural Anthropology 31, no. 1: 82-106. https://doi.org/10.14506/ca31.1.05.

Suarez, Maka

2017 "The Subprime Middle Class: Precarious Labor, Mortgage Default, and Activism among Ecuadorian Migrants in Barcelona.” PhD dissertation, Goldsmiths, University of London.

Tsing, Anna

2000 "The Global Situation.” Cultural Anthropology 15, no. 3: 327-60. https:// doi.org/10.1525/can.2000.15.3.327.

Vicens Vives, Jaime

1969 An Economic History of Spain. Translated by Frances M. López-Morillas. Princeton, Weston, Kath N.J: Princeton University Press. Originally published in 1955.

2013 "Lifeblood, Liquidity, and Cash Transfusions: Beyond Metaphor in the Cultural Study of Finance." Journal of the Royal Anthropological Institute 19, no. S1: S24 Zaloom, Caitlin 41. https://doi.org/10.1111/1467-9655.12014.

2006 Out of the Pits: Traders and Technology from Chicago to London. Chicago: University of Chicago Press.

2014 “Traders and Market Morality." In The Oxford Handbook of the Sociology of Finance, edited by Karin Knorr Cetina and Alex Preda, 169-86. New York: Oxford University Press. 